\title{
Effect of Health Belief Model Based Nutrition Education on Dietary Habits of Secondary School Adolescent Girls in Sharkia Governorate
}

\author{
Ghada M. Salem and Randa M. Said \\ Department of Community Medicine, Faculty of Medicine, Zagazig University, Egypt.
}

$\underline{\text { Received: July } 2017 \quad \text { Accepted : November } 2017}$

\begin{abstract}
Background: Adolescents need much attention as they constitute one-fifth of the total population and about $84 \%$ of this population live in developing countries. Also, they are susceptible to poor nutritional status if they do not meet their increased nutritional needs because of growth spurt, psychological and sexual maturity and cognitive development occurring during this period. Objectives: To assess the dietary habits of secondary school adolescent girls before and after an intervention nutrition education program. Methods: an intervention study was conducted on 108 adolescent girls aged between 15-17 years from one of female secondary governmental schools in Zagazig district at Sharkia Governorate, Egypt from September 2015 to February 2016. The study was performed in three stages; the $1^{\text {st }}$ stage was assessment of dietary habits by a valid pretested dietary questionnaire on food habits, eating behavior and nutritional knowledge that was modified by adding a new section on Health Belief Model constructs, the $2^{\text {nd }}$ stage was application of Health Belief Model (HBM) based nutrition education program, and the $3^{\text {rd }}$ stage was reassessment of the same study participants with the same questionnaire to assess the effectiveness of intervention. Results: Nutrition education has significantly improved the consumption pattern of different foods where the percent of girls who followed the servings of healthy food groups and avoid consumption of unhealthy foods (fast, fried, canned foods), unhealthy drinks (carbonated and caffeinated drinks), and excess intake of salt and sugar/sweet were significantly increased after nutrition education. The percent of girls who followed recommended dietary, lifestyle and physical activity and food safety and behavior in hygiene practices had statistically significantly increased after intervention $(\mathrm{P}<0.05)$. After intervention there was an improvement in the mean of nutrition knowledge score from $(4.77 \pm 2.7)$ to $(6.2 \pm 2.1)$. The mean knowledge on healthy and unhealthy lifestyle habits and foods was improved from $(2.36 \pm 1.01)$ to $(3.8 \pm 0.68)$. The mean knowledge score on food safety was improved from (3.79 \pm 2.54$)$ to $(6.0 \pm 1.68)$, all with $(\mathrm{p}<0.05)$. The mean scores of Health Belief Model constructs were significantly improved. Conclusion and recommendation: Nutrition education based on HBM brought significant improvements in not only nutritional knowledge of adolescent girls but also translated some of them into action. HBM-based strategies can be recommended as effective communication channels to improve dietary habits of female students.
\end{abstract}

Key words: adolescent girls, nutrition behaviors, HBM.

Corresponding author: GhadaM. Salem Email gadamaged2@gmail.com

\section{Introduction}

Adolescent need much attention as they constitute one-fifth of the total population and about $84 \%$ of population lives in developing countries. Also, they are susceptible to poor nutritional status if they don't meet their increased nutritional needs because of growth spurt, psychological and sexual maturity

$\begin{array}{llll}\text { Vol. } 36 & \text { No. } 3 & \text { July } & 2018\end{array}$


and cognitive development occurring during this period. Increased physical activity combined with poor eating habits contribute to poor nutritional status of this population. For adolescent girls, in particular, their nutritional needs are often neglected; also, menstruation and adolescent pregnancy contribute to their poor nutritional status. ${ }^{1}$ Nutrition is the main factor in the advancement and maintenance of good health during the whole life cycle. It is a major modifiable determinant of chronic noncommunicable diseases and it, therefore, occupies a prominent position in the prevention activities. Healthy eating habits found to be established in childhood and maintained during adolescence to prevent diet-related chronic diseases. $^{2}$

Poor dietary habits of adolescent girls influence their present health through developing nutritional problems like obesity and anemia which have become growing problems in Egypt as about $34.7 \%$ of female adolescents are overweight or at the risk of being overweight and about $17.6 \%$ are obese. ${ }^{3}$ About $54.03 \%$ of female adolescent are anemic $^{4}$ and other micronutrient deficiency disorders that result in growth retardation, low immunity to disease and reduced reproductive functions that lead to some pregnancy-related deaths or result in delivering low birth weight babies, thus perpetuating the transgenerational cycle of malnutrition. ${ }^{5}$ Those habits may not only influence the present health but may also determine whether or not an individual develops diseases such as cancer and other chronic diseases later in life. ${ }^{6}$

It is perceived that these poor eating habits are as a result of peer pressure, parents' dietary habits, media exposure, the increase in fast food centers in urban cities $^{7,8}$ and lack of knowledge of adolescents about the cumulative effects of their poor eating habits. ${ }^{6}$ For the above reasons and as the most adolescents are most expected to be responsible about their diets for the first time (away from home); therefore, they need guidance on how to make informed choices. ${ }^{9}$ This guidance can be developed through nutrition education programmed that promote the healthy food choices and good eating habits.

To make behavioral modification, understanding the health beliefs of adolescents is particularly essential. The Health Belief Model (HBM) is one of the most used outlines developed to understand health behavior. The HBM is recommended for nutrition education programs to increase their impact. ${ }^{10}$ The constructs of this model are perceived susceptibility, severity, threat, benefits and barriers, self-efficacy, cues to action, and taking health action. ${ }^{11,12}$ Therefore, the study aimed to study whether the application of HBM-based nutrition education can be effectively used in changing the dietary habits of adolescent girls in high schools. The hypothesis was that nutrition education based on HBM can improve the dietary habits among female students of secondary schools. The specific objectives were to assess the dietary habits of secondary school adolescent girls before and after intervention.

\section{Methods}

Design and setting of the study: An intervention study (a quasi-experimental design of the pretest-posttest method) was conducted from September 2015 to February 2016 at female secondary governmental schools in Zagazig district in Sharkia Governorate. The study was passed in three stages, the $1^{\text {st }}$ stage for assessment of dietary habits of the adolescent girls, the 2nd stage for applying a NE program then 3rd stage was done after three months from the last educational session to evaluate the intervention.

Study subjects and sampling methods: They were adolescent females aged 
between 15-17 years chosen by multistage sampling technique where one school was chosen randomly from seven female secondary governmental schools at Zagazig district, then two classes out of ten classes in each grade were chosen randomly then by using simple random sampling method from the school sheets of selected classes, the sample was taken. Sample size was calculated by Open Epiinfo program at C.I 95\%, power of test $80 \%$, ratio of sample size $1: 1$, the mean of nutrition knowledge before intervention was $(46.73 \pm 15.14)$ that changed to $(58.86 \pm 16.13)$ after intervention ${ }^{1}$, so total sample size was 54 subjects and with duplication of the sample size to prevent sample error then total sample size was 108 adolescent females. Inclusion criteria were willingness to participate in this study and completing the required questionnaire.

Tools of data collection: dietary questionnaire on food habits, eating behavior and nutritional knowledge which was developed and validated for use among adolescent girls in previous study. ${ }^{13}$ It was translated into Arabic and modified to be seven sections instead of nine where dietary, physical activity and lifestyle habits were put under one section instead of two in original questionnaire and self-efficacy and barriers to change sections in original questionnaire were put under one newly developed section called HBM constructs. The seven sections included: (1) Frequency of food consumption: 28 items that were classified into 14 food groups and drinks during analysis, including bread/rice, animal proteins, plant proteins, dairy products, vegetables, fruits, fast foods, fried foods, canned foods, carbonated soft drinks, tea, salt, sugar/sweet, and water. The frequency of subjects who followed servings (number and size /day) of these groups was compared before and after intervention.
(2) Dietary, physical activity and lifestyle habits (6 items) scored 1 to 4 whereby $4=$ healthiest habit. The frequency of subjects who followed the healthiest habit was compared before and after intervention. (3) Food safety and behavior in hygiene practice (6 items), mainly answered; always, often, sometimes and never. Scored 1 to 4 with healthiest response $=4$. The frequency of subjects who recorded the healthiest response was compared before and after intervention. (4) Knowledge on healthy and unhealthy diet and food (5 items); scored 1 for true response, 0 for others. The mean of total score which equal five was compared before and after intervention. (5) Nutrition knowledge (11 items); scored 1 for true response, 0 for others. The mean of total score which equal 11 was compared before and after intervention. (6) Food safety knowledge (10 items); scored 1 for true response, 0 for others. The mean of total score which equal ten was compared before and after intervention. (7) The questionnaire included 32 questions to assess the HBM constructs (14) including perceived susceptibility (2 questions), perceived severity (2 questions), perceived benefit (8 questions), perceived barriers(14 questions), perceived self-efficacy (4 questions) and cues to action (2 questions). The questions were evaluated by four option Likart scale with score 1 as the weakest and 4 as the most desirable. The frequency of subjects who recorded the most desirable score was compared before and after intervention. Also the mean of HBM constructs scores was compared before and after intervention.

All participants were asked to complete the questionnaire on two separate occasions (pre-intervention, and three months since the last session to evaluate the effectiveness and stability of the NE program. The students were instructed on how to estimate the food eaten in frequency at the initial visit. 
Pilot study: It was done (10 adolescent girls who were chosen randomly and excluded from the study about $10 \%$ of the study sample). It was done to assess the reliability of the questionnaire where the same questionnaires were redistributed to the same 10 girls after 2 weeks and the result was similar. The questionnaire was assessed and some modifications were done after pilot study.

Nutrition Education program prepared after assessing knowledge and dietary practice of the adolescent girls by using questionnaire to ensure covering the gaps in the nutrition knowledge and healthy dietary practice of the adolescent girls. A topics plan of $\mathrm{NE}$ was structured to determine the educational content of each session (Table 1). Content of the educational programmed was developed according to this topics plan. All the students included in the study received six 45-minutes to one-hour sessions during a two-month period according to a topics plan based on the HBM. According to this model, the NE program included objectives based on individual perceptions (perceived susceptibility and perceived severity) and likelihood of action (perceived benefits, perceived barriers, and taking health action) that influence the healthy eating behavior of the students (Table 6).

The educational program was presented to the students through short lectures and visual education materials, such as slide shows illustrating all essential information with pictures of the food guide pyramid, healthy eating plate, food-groups, poor dietary and lifestyle habits, food safety and hygiene practice. Simulation was used to represent serving size of different foods with dishes, cups, and bottles models of known size. The students were also taught how to calculate their daily energy requirements to maintain normal weight, nutrient contents (energy, calcium, protein, etc.) in a serving, and recommended daily requirements of each nutrient. The educational content of each session was disseminated to the students after the end of the session as an educational pamphlet prepared by researchers. At the end of each nutrition education session, there was enough time for questions and discussions.

Statistical methods: IBM SPSS program version 20.0 was used to calculate frequencies and perform the appropriate statistical tests including paired-t and McNemar tests.

Administrative design and Ethical issues: The research protocol was approved by Ethics Committee of Faculty of Medicine, Zagazig University, Egypt and the reference number is ZUIRB\#: 2163/31-5-2015.Official permission was got from the educational directorate, district and administrator of the school. The study group was informed about the purpose and significance of the study and a written consent to participate in the study was obtained from each participant. The participants were reassured that their information will remain confidential.

\section{Results:}

The study involved 108 secondary school adolescent girls. Their age ranged from 15 to 17 with a mean of $15.77 \pm 0.7$ years. Nutrition education significantly improved the consumption pattern of different foods where the percent of subjects who followed the servings of healthy food groups and avoid consumption of unhealthy foods (fast, fried, canned foods), unhealthy drinks (carbonated and caffeinated drinks), and excess intake of salt and sugar/sweet was significantly increased after NE (Table 2). Nutrition education significantly improved the dietary habits of adolescent girls where the percent of subjects who skipped no meals was increased from (48.1)to (78.7), ate breakfast regularly was increased from (48.1) to (68.5), avoided drinking tea immediately after 
Table 1: Main Topics in nutrition education

\begin{tabular}{|c|c|}
\hline Session title & Contents \\
\hline Principles of proper nutrition & $\begin{array}{l}\text { - Different food elements, sources, and mainl } \\
\text { functions in the body } \\
\text { - Meaning of healthy balanced diet } \\
\text { - Food guide pyramid idea }\end{array}$ \\
\hline Food-groups & $\begin{array}{l}\text { - Nutrient stuffing (energy, calcium, protein, etc.) } \\
\text { in a serving } \\
\text { - Daily dietary needs for female adolescents }\end{array}$ \\
\hline Healthy lifestyle & $\begin{array}{l}\text { - Healthy dietary habits } \\
\text { - Suggested physical activity and its importance } \\
\text { - Hazards of fast foods and unrestricted use of } \\
\text { T.V and internet }\end{array}$ \\
\hline $\begin{array}{l}\text { Food safety and hygiene } \\
\text { practice }\end{array}$ & $\begin{array}{l}\text { - } \text { Meaning of food safety } \\
\text { - Hygiene practices during preparation and } \\
\text { safeguarding of food }\end{array}$ \\
\hline Malnutrition disorders & $\begin{array}{l}\text { - Obesity and its hazards } \\
\text { - Micronutrient deficiency symptoms }\end{array}$ \\
\hline & $\begin{array}{l}\text { - In the last session, the materials existing in the } \\
\text { previous sessions were repeated and } \\
\text { summarized through a question-and-answer } \\
\text { session }\end{array}$ \\
\hline
\end{tabular}

Table 2: Recommended consumption pattern of different food groups of adolescent girls before and after nutrition education

\begin{tabular}{|l|r|r|c|}
\hline \multicolumn{1}{|c|}{ Recommended consumption pattern } & $\begin{array}{c}\text { Before } \\
\text { education } \\
\text { No (\%) }\end{array}$ & $\begin{array}{c}\text { After } \\
\text { education } \\
\text { No(\%) }\end{array}$ & $\begin{array}{c}\text { McNemar } \\
\text { Test } \\
\text { P value }\end{array}$ \\
\hline Bread/rice & $57(52.8)$ & $84(77.7)$ & $<0.001$ \\
Animal proteins & $18(16.6)$ & $25(23.1)$ & 0.03 \\
Plant proteins & $52(48.1)$ & $81(75.0)$ & $<0.001$ \\
Dairy products & $37(34.2)$ & $86(79.6)$ & $<0.001$ \\
Vegetables & $51(47.2)$ & $90(83.3)$ & $<0.001$ \\
Fruits & $36(33.3)$ & $44(40.7)$ & 0.03 \\
Fast foods & $32(29.6)$ & $86(79.6)$ & $<0.001$ \\
Fried foods & $22(20.3)$ & $28(25.9)$ & 0.02 \\
Canned foods & $52(48.1)$ & $86(79.6)$ & $<0.001$ \\
Carbonated soft drinks & $21(19.4)$ & $88(81.5)$ & $<0.001$ \\
Tea & $15(13.8)$ & $75(69.4)$ & $<0.001$ \\
salt & $50(46.3)$ & $66(61.1)$ & $<0.001$ \\
sugar/sweet & $25(23.1)$ & $74(68.5)$ & $<0.001$ \\
water & $27(25.0)$ & $71(65.7)$ & Paired t $=9.68$ \\
\hline Total score $(X \pm$ SD) & $6.047 \pm 4.52$ & $9.74 \pm 4.16$ & P value $<0.001$ \\
\hline
\end{tabular}


Table 3: Recommended dietary, lifestyle and physical activity habits of adolescent girls before and after nutrition education

\begin{tabular}{|c|c|c|l|}
\hline $\begin{array}{c}\text { McNemar } \\
\text { Test } \\
\text { P value }\end{array}$ & $\begin{array}{c}\text { Post } \\
\text { education } \\
\text { No(\%) }\end{array}$ & $\begin{array}{c}\text { Pre } \\
\text { education } \\
\text { No(\%) }\end{array}$ & \multicolumn{1}{|c|}{ Positive habits } \\
\hline$<0.001$ & $85(78.7)$ & $52(48.1)$ & No meal skipped \\
$<0.001$ & $74(68.5)$ & $52(48.1)$ & Eating breakfast regularly \\
$<0.001$ & $42(38.9)$ & $26(24.1)$ & Taking snakes of fruits or vegetables \\
$<0.001$ & $54(50.0)$ & $29(26.9)$ & Watching TV $\leq \mathbf{2}$ hours/ day \\
$<0.001$ & $54(50.0)$ & $40(37.0)$ & Not using Internet every day \\
$<0.001$ & $36(33.3)$ & $24(22.2)$ & Practicing physical activity $\geq \mathbf{4 h} /$ week \\
\hline Paired t $=6.81$ & $4.1 \pm 1.07$ & $3.46 \pm 1.28$ & Total score (Mean \pm SD) \\
P value $<0.001$ & \multicolumn{3}{|l}{} \\
\hline
\end{tabular}

Table 4: food safety and behavior in hygiene practices of adolescent girls before and after nutrition education

\begin{tabular}{|c|c|c|l|}
\hline $\begin{array}{c}\text { McNemar } \\
\text { Test } \\
\text { P value }\end{array}$ & $\begin{array}{c}\text { Post } \\
\text { education } \\
\text { No (\%) }\end{array}$ & $\begin{array}{c}\text { Pre } \\
\text { education } \\
\text { No }(\%)\end{array}$ & \multicolumn{1}{|c|}{$\begin{array}{c}\text { Food safety and behavior in hygiene } \\
\text { practices }\end{array}$} \\
\hline$<0.001^{*}$ & $84(77.8)$ & $52(48.1)$ & $\begin{array}{l}\text { When you buy a packaged food, you check } \\
\text { the expiry date }\end{array}$ \\
\hline$<0.001^{*}$ & $76(70.4)$ & $57(52.8)$ & $\begin{array}{l}\text { You read the instruction for use and for } \\
\text { preservation written on the packaged foods }\end{array}$ \\
\hline$<0.001^{*}$ & $88(81.5)$ & $64(59.3)$ & $\begin{array}{l}\text { You wash your hands before eating and } \\
\text { before touching foods }\end{array}$ \\
\hline$<0.001^{*}$ & $96(88.9)$ & $69(63.9)$ & $\begin{array}{l}\text { You usually wash fruits that must not be } \\
\text { pealed before eating it }\end{array}$ \\
\hline$<0.001^{*}$ & $103(95.4)$ & $81(75.0)$ & $\begin{array}{l}\text { You usually put the remaining milk in the } \\
\text { fridge after drinking }\end{array}$ \\
\hline$<0.001^{*}$ & $98(90.7)$ & $84(77.8)$ & $\begin{array}{l}\text { You throw the milk away if you realize you } \\
\text { have left it out of fridge during the night }\end{array}$ \\
\hline $\begin{array}{l}\text { Paired } \mathbf{t}=19 \\
\text { P value }<0.001\end{array}$ & $3.95 \pm 1.44$ & $2.56 \pm 1.65$ & Total score (Mean \pm SD) \\
\hline
\end{tabular}

Table 5: diet related knowledge of adolescent girls before and after nutrition education

\begin{tabular}{|c|c|c|c|l|}
\hline P value & $\begin{array}{c}\text { Paired t } \\
\text { test }\end{array}$ & $\begin{array}{c}\text { Post education } \\
(\mathbf{X} \pm \text { S.D) }\end{array}$ & $\begin{array}{c}\text { Pre education } \\
(\mathbf{X} \pm \text { S.D) }\end{array}$ & \multicolumn{1}{|c|}{ Items } \\
\hline$<0.001^{*}$ & 10.4 & $6.2 \pm 2.1$ & $4.77 \pm 2.7$ & Nutrition knowledge \\
\hline$<0.001^{*}$ & 20.125 & $3.8 \pm 0.68$ & $2.36 \pm 1.01$ & $\begin{array}{l}\text { Knowledge on healthy and } \\
\text { unhealthy dietary habits and } \\
\text { foods }\end{array}$ \\
\hline$<0.001^{*}$ & 16.4 & $6.0 \pm 1.68$ & $3.79 \pm 2.54$ & Knowledge on food safety \\
\hline
\end{tabular}


Table 6: health beliefs related to eating healthy diet of adolescent girls before and after nutrition education

\begin{tabular}{|c|c|c|}
\hline $\begin{array}{l}\text { Post } \\
\text { education } \\
\text { No }(\%)\end{array}$ & $\begin{array}{l}\text { Pre } \\
\text { education } \\
\text { No }(\%)\end{array}$ & Health beliefs related to eating healthy diet \\
\hline $\begin{array}{l}42(38.9)^{*} \\
45(41.6)^{*}\end{array}$ & $\begin{array}{l}20(18.5) \\
25(23.1)\end{array}$ & $\begin{array}{l}\text { Perceived Susceptibility: } \\
\text { I have poor dietary habits } \\
\text { I'm at risk of obesity or other malnutrition disorders }\end{array}$ \\
\hline $\begin{array}{l}96(88.9)^{*} \\
86(79.6)^{*}\end{array}$ & $\begin{array}{l}66(61.1) \\
65(60.2) \\
\end{array}$ & $\begin{array}{l}\text { Perceived Severity: } \\
\text { Malnutrition is a health problem } \\
\text { Obesity leads to severe complications }\end{array}$ \\
\hline $\begin{array}{l}99(91.7)^{*} \\
90(83.3)^{*} \\
95(87.9)^{*} \\
99(91.7)^{*} \\
96(88.9)^{*} \\
85(78.7)^{*} \\
76(70.3)^{*} \\
64(59.2)^{*}\end{array}$ & $\begin{array}{l}56(51.9) \\
73(68.5) \\
79(73.5) \\
47(44.1) \\
66(61.8) \\
66(61.3) \\
56(52.5) \\
34(37.0)\end{array}$ & $\begin{array}{l}\text { Perceived Benefits: } \\
\text { Improving health } \\
\text { Feeling energetic } \\
\text { Feeling good about myself } \\
\text { Lowering cholesterol } \\
\text { Losing weight or maintaining desired weight } \\
\text { Testing willpower } \\
\text { Improving appearance } \\
\text { Saving money }\end{array}$ \\
\hline $\begin{array}{r}48(44.9) \\
57(52.7) \\
85(78.7)^{*} \\
51(47.4) \\
76(70.3)^{*} \\
71(66.2)^{*} \\
83(77.6)^{*} \\
48(44.7)^{*} \\
35(32.6) \\
35(32.6) \\
24(22.2)^{*} \\
20(18.5)^{*} \\
8(7.4)^{*} \\
10(9.2)^{*} \\
\end{array}$ & $\begin{array}{l}49(45.4) \\
55(50.9) \\
41(38.3) \\
51(47.4) \\
38(35.6) \\
37(34.3) \\
35(32.6) \\
34(32.4) \\
39(36.1) \\
38(35.2) \\
34(32.1) \\
39(36.9) \\
28(26.0) \\
26(24.9)\end{array}$ & $\begin{array}{l}\text { Perceived Barriers: } \\
\text { Foods that fit into a healthier diet are not available at home } \\
\text { I find it difficult to make healthy food choices at the school canteen } \\
\text { I do not know which foods are best to reduce sugar and fat } \\
\text { I have no control over the foods available at home } \\
1 \text { do not know how many calories are in different foods } \\
\text { I do not know which foods are high in fiber } \\
\text { I have trouble knowing how much I should eat } \\
\text { I have trouble sticking to a healthy diet } \\
\text { I have trouble choosing healthy foods when I am out with family or friends } \\
\text { My family does not support my efforts to eat a healthier diet } \\
\text { I don't see any benefit from my efforts to eat a healthier diet } \\
\text { It is difficult to find time to plan healthy meals } \\
\text { I use food as a treat or reward for myself } \\
\text { I find that a healthy diet is too expensive }\end{array}$ \\
\hline $\begin{array}{l}89(82.4)^{*} \\
86(79.6)^{*} \\
84(77.8)^{*} \\
96(88.9)^{*}\end{array}$ & $\begin{array}{l}67(62.0) \\
68(63.0) \\
69(63.9) \\
76(70.4)\end{array}$ & $\begin{array}{l}\text { Perceived Self efficacy: } \\
\text { I will be able to modify my diet } \\
\text { I will be able to stick to a healthy diet } \\
\text { I will be able to lose or to gain weight if needed } \\
\text { I will be able to practice a constant physical activity }\end{array}$ \\
\hline $\begin{array}{l}92(85.2)^{*} \\
63(58.3)^{*}\end{array}$ & $\begin{array}{l}42(38.9) \\
44(40.7)\end{array}$ & $\begin{array}{l}\text { Cues to action: } \\
\text { I have meaningful education about healthy foods and healthy dietary habits } \\
\text { I know someone suffer from complication of obesity or malnutrition }\end{array}$ \\
\hline
\end{tabular}


Table 7: Comparison between health beliefs model constructs related to eating healthy diet of adolescent girls before and after nutrition education

\begin{tabular}{|c|c|c|c|l|}
\hline P value & $\begin{array}{c}\text { Paired t } \\
\text { test }\end{array}$ & $\begin{array}{c}\text { Post education } \\
\text { (Mean } \pm \text { S.D) }\end{array}$ & $\begin{array}{c}\text { Pre education } \\
\text { (Mean } \pm \text { S.D) }\end{array}$ & \multicolumn{1}{|c|}{ Items } \\
\hline$<0.001$ & 3.9 & $4.7 \pm 2.7$ & $4.2 \pm 2.3$ & Perceived Susceptibility \\
\hline$<0.001$ & 6.2 & $7.1 \pm 1.9$ & $6.2 \pm 2.3$ & Perceived Severity \\
\hline$<0.001^{]}$ & 8,7 & $28.1 \pm 6.4$ & $24.09 \pm 8.4$ & Perceived Benefits \\
\hline$<0.001$ & 3.7 & $31.9 \pm 16.6$ & $34.4 \pm 12.8$ & Perceived Barriers \\
\hline$<0.001$ & 5.5 & $14.2 \pm 3.5$ & $12.8 \pm 4.3$ & Perceived Self efficacy \\
\hline$<0.001$ & 8.5 & $5.6 \pm 2.01$ & $4.8 \pm 2.6$ & Cues to action \\
\hline
\end{tabular}

food was increased from (54.6) to (67.6), drank at least $1-1.5 \mathrm{~L}$ of water daily was increased from (25.0) to (65.7), and took healthy snakes of fruits and vegetables was increased from (24.1) to (38.9) (Table 3). Also this table showed that nutrition education significantly improved the lifestyle habits of respondents where the percent of subjects who watched TV $\leq 2$ hours/ day was increased from (26.9) to (50.0), avoided using Internet every day was increased from (37.0) to (50.0) and practiced physical activity $\geq 4 \mathrm{~h} /$ week was increased from (22.2) to (33.3).

Nutrition education significantly improved the food safety and behavior in hygiene practices of adolescent girls ( $\mathrm{p}$ $<0.05$ ) (Table 4) and also improved the mean of their nutrition knowledge from $(4.77 \pm 2.7)$ to $(6.2 \pm 2.1)$, the mean of their knowledge on healthy and unhealthy lifestyle habits and foods from $(2.36 \pm 1.01)$ to $(3.8 \pm 0.68)$, and the mean of their knowledge on food safety from $(3.79 \pm 2.54)$ to $(6.0 \pm 1.68)$, all with (p $<0.05)$ (Table 5).

Nutrition education significantly changed the beliefs of adolescent students regarding healthy dietary habits (Table 6). The mean scores of HBM constructs were also statistically significantly improved after intervention, perceived susceptibility $(\mathrm{p}<0.001)$, perceived severity $(\mathrm{p}<0.001)$, perceived benefits $(p<0.001)$, perceived barriers $(p<0.001)$, self efficacy $(p<0.001)$ and cues to action $(p<0.001)$. (Table 7).

\section{Discussion:}

This study highlighted the effectiveness of NE on healthy dieting knowledge, beliefs, and behaviors among adolescent girls in secondary schools. The anthropometric measurements were out of the study focus since the goal of the NE was not to decrease weight and BMI, but to improve student eating behaviors. $\mathrm{NE}$ was an effective tool in improving the consumption pattern of different foods among respondents' .Bread and rice are the constant foods for majority of the Egyptians and about $90 \%$ of adolescents reported daily consumption of these foods. ${ }^{15}$ This study reported that only about $50 \%$ of subjects followed the recommended servings of this group prior to NE. After imparting NE, the percent of subjects who follow the recommended serving was statistically significantly increased to about $77.7 \%$. This may reflect the effective role of NE in prevention of excess carbohydrate intake related problems like obesity and diabetes.

Although the percent of subjects who followed the servings of animal proteins was also statistically significantly increased after NE, the consumption of animal proteins is still low among adolescents because of the high cost .This was consistent with Abdel-Hady et al. ${ }^{15}$ who reported that only one-fourth of adolescents reported daily consumption of animal proteins with high 
socioeconomic standard as the most important determining factor. For plant proteins, the percent of subjects who followed the servings of this group was highly significantly increased after NE due to focusing of education to make plant proteins equivalent alternatives with affordable costs to animal proteins.

As dairy products are an important source of essential micronutrients and a combination of macronutrients, their role is well known in building and maintaining strong bones. ${ }^{16}$ Although being cheaper and available to all sectors of the population, only about one third of subjects followed the recommended servings of dairy products prior to NE. After NE, the percent of subjects was highly significantly increased to about $80 \%$. Consumption of fruits and vegetables is also associated with reduced risk for chronic diseases and some cancers. Low consumption of fruits and vegetables in many regions of the developing world is a persistent phenomenon, confirmed by the findings of food consumption surveys. ${ }^{17}$ Although the percent of subjects who followed the serving of vegetables and fruits was significantly increased after NE. The consumption of fruits is still low among respondents. This may be attributed to the different consumption of fruits and vegetables between social classes and this is in agreement with the survey of young people in Egypt (SYPE) which reported that fruits consumption is markedly correlated with social class, being higher in the highest wealth. ${ }^{18}$

NE was effective in reducing the consumption of unhealthy food choices among adolescents. Fast foods represent popular unhealthy choices and a way of life for many adolescents because they are inexpensive, familiar, and available at almost any time and because many adolescents socialize with their peers at fast food restaurants. ${ }^{19}$ The fast foods are usually in the form of fried foods which are harmful to health as Stott-Miller ${ }^{20}$ founded that deep frying may trigger formation of carcinogens in food and people who consumed fast/fried foods $\geq$ once weekly were at high risk for prostate cancer and other types of cancers than who consumed them $\leq$ once monthly. After NE, the percent of subjects who consumed fast and fried foods $\leq$ once monthly was statistically significantly increased but with high significance to fast food $(\mathrm{p}=0.00)$ and slight significance to fried food $(\mathrm{p}=$ 0.02 ). This reflects the ability of adolescents to control themselves and stop consumption of fast foods outside the home. While they have limited control over their consumption of fried food prepared at home indicating that their education alone without their mothers who are responsible for preparation of food at home is not enough.

Canned foods are also unhealthy food choices. They contain Biphenyl-A(BPA) which is a toxic chemical that causes hormone imbalances and wide variety of health issues ranging from hypertension, aggression,

obesity to cancer and heart disease. They also lead to Aluminum accumulation in body which can cause memory problem like Alzheimer's. They contain 80\%less nutrient than fresh fruits and vegetables. They can predispose to salmonella outbreak. $^{21}$ The percent of subjects who followed the recommended consumption of canned foods was statistically significantly increased after NE $(\mathrm{p}<0.001)$.

$\mathrm{NE}$ was effective in reducing consumption of unhealthy drinks among adolescents. In Egypt the drinks depend on natural substances are replaced by commercially carbonated soft drinks which entail a significant increase in daily sugar intake apart from depriving the body of the health benefits of the natural beverage. ${ }^{22}$ The percent of subjects who consumed small sized portions of carbonated soft drinks $\leq$ once 
weekly was statistically significantly increased after NE $(\mathrm{P}<0.001)$. The habit of consuming sweetened black tea is also popular in Egypt and represents a national habit. ${ }^{22}$ Drinking plain (caloriefree) tea provides a variety of flavonoids and antioxidants and other biologically active substances that may be good for health. ${ }^{23}$ Tea contains caffeine, which should be limited to less than 2.5 $\mathrm{mg} / \mathrm{kg} /$ day for $\geq 12$ year children to avoid its health hazards. ${ }^{24}$ Prior to NE, the majority or subjects consumed tea in a wrong way either consumed sweetened or more than the recommended amount or immediately after meals which prevent absorption of iron and predisposed to anemia or all together but after NE, the percent of subjects who followed the recommended consumption of tea was statistically significantly increased $(\mathrm{P}<0.001)$. Water is the cornerstone for all body functions. It's the richest substance in the body, about 60 percent of body weight. To get enough water, the child or teen should drink at least 6 to 8 cups of water a day and eat the recommended number of servings of fruits and vegetables every day. ${ }^{25}$ After NE, the percent of subjects who followed the recommended consumption of water was statistically significantly increased $(\mathrm{P}<0.001)$.

Prior to NE, the majority of respondents reported excess consumption of salts and sugars in the form of salty snacks, cakes, sweets, and chocolates which are the most available snacking choices at school canteens and supermarkets. The frequent consumption of snacks is a recognized aspect of teenage food behavior. ${ }^{26}$ After $\mathrm{NE}$, there was statistically significant reduction in the percent of respondents who consumed excess salts and sugars. The nature of the snakes was changed to be of fruits and vegetables in a significant no of respondents.

The effect of nutrition education is clearly visible on the dietary habits of the respondents. Meal skipping was found to be common practice among more than half of the subjects and breakfast was found to be most frequently missed meals. However, after nutrition education, practice of meal skipping reduced and the practice of regular breakfast intake increased. Similarly, Kaur et al. ${ }^{27}$ reported that practice of meal skipping reduced (from 43 to 24) and skipping of breakfast and lunch by the respondents also reduced from 29 and 12 to 16 and 8 respectively after imparting nutrition education. NE also statistically significantly improved the lifestyle habits of respondents $(\mathrm{p}<0.001)$. It was found that overweight and obesity among school children are directly related to the amount of time spent in front of a TV set or personal computer. ${ }^{28}$ After NE, the percent of subjects who watched TV $\leq 2$ hours/ day was increased from (26.9) to (50.0), avoided using Internet every day was increased from (37.0) to (50.0).In children and adolescents alike, maintaining an optimal level of physical activity is particularly important as it not only reduces the risk of overweight but also improves body composition and the growth pattern ${ }^{(29)}$. After NE, the percent of subjects who practiced physical activity $\geq 4 \mathrm{~h} /$ week was increased from (22.2) to (33.3).

NE statistically significantly improved the food safety and behavior in hygiene practices of respondents. This is in agreement with Kim et al. ${ }^{30}$ who found that after food safety education by highschool mentors, middle-school students who were in the stages of precontemplation $\quad(11.1 \%) \quad$ and contemplation $\quad(88.9 \%) \quad$ showed significant progression toward the action stage $(\mathrm{P}<0.001)$.

$\mathrm{NE}$ also statistically significantly improved the mean of diet related knowledge of respondents. Findings of the present study are in concurrence with the study Sharma and Chawla ${ }^{31}$ who observed highly significant gain in nutrition knowledge of 13-14 yrs old 
school girls after imparting nutrition education. The findings of the present study are also with the findings of Kaur et al. ${ }^{27}$ who found that the mean nutrition knowledge scores $11.17 \pm 1.42$ obtained in pretest was significantly $(\mathrm{P}<0.01)$ increased to $19.16 \pm 1.8$ after imparting nutrition education. Kim et al. $^{30}$ found that proper hand washing $(\mathrm{P}<0.01)$ and food safety knowledge $(\mathrm{P}<0.05)$ were also significantly increased after educational intervention.

In this study, HBM constructs (perceived susceptibility, severity, benefits, barriers, self-efficacy and cues to action) scores showed an improvement following NE program. This study showed that students believed after the intervention that they were susceptible to malnutrition with its complications related to their poor dietary habits. This belief may have led to take action to protect their health. ${ }^{32}$ Also; there was a decrease in perceived barriers after NE program except those related to control of food choices at home, in school canteen, and with friends outside home. Other studies indicated that a health education program based on the HBM appeared to have been more effective in improving the dietary habits like increasing daily calcium intake than traditional health education or 'no' education in female students of middle school. $^{33}$

\section{Conclusion and recommendations}

Nutrition education based on HBM brought significant improvements in not only nutritional knowledge of adolescent girls but also translated some of them into action. As girls would benefit from the programmed that promote the awareness that healthy food are suitable way to control on their weight because of the alarming prevalence of overweight and obesity among the girls.

HBMbased approaches can be recommen ded as effective communication passages to improve dietary habits of female students. Nutrition professionals should work with parents to provide nutritional knowledge to the adolescent girls. As encourages the parent to make health foods regularly available to their adolescents.

\section{References}

1. RaghunathaRaoD, Vijayapushpam T, SubbaRao GM, Antony GM and SarmaKVR: Dietary habits and effect of two different educational tools on nutrition knowledge of school going adolescent girls in Hyderabad, Euro $\mathbf{J}$ of Clinical Nutrition 2007; 61, 1081-1085.

2. WHO. The world health report: reducing risks, promoting healthy life. Geneva,World Health Organization; 2002.

3. Egypt Demographic and Health survey (2014).final report. Available at http://www. dhsprogram.com.

4. SolimanGh Z A, Azmi M N, and El-S

S: Prevalence of Anemia in Egypt (AlGharbia Governorate). EJHM2007; 28: 295-305.

5. Bhaskaram P (2001): The cycle of malnutrition and women's health. Nutr News 2001; 22, 1-6.

6. Anetor $\mathrm{G} \mathrm{O}$, OgundeleB $\mathrm{O}$, and Oyewole $\mathrm{O}$ E: Effect of nutrition education on the eating habits of undergraduates in South-West, Nigeria. Asian Journal of Epidemiology2012; 5 (2):32-41.

7. Akinwusi $\mathrm{A} \mathrm{T}$ and Ogundele $\mathrm{B} \mathrm{O}$ : Influence of economy, society and personal beliefs on nutritional habits. Nig. Sch. Health2005; 17:143-149.

8. Ajala J A: Understanding Food and Nutrition: eat for health; you are what you eat. May Best Publications. Akinwusi, Ibadan 2006; P: 162.

9. Satia J A, Galanko J A and SiegaRizA M: Eating at fast restaurants is associated with dietary intake, demographic, psychosocial and behavioral factors among African Americans in North Carolina. Public Health Nut2004; 7: 1089-1096.

10. Rosenstock IM, KirschtJP:The health belief model and personal health 
behavior. Health Educ Monogr.1974; 2:470-3.

11. Lynch L, Happell B: Implementation of clinical supervision in action. Part 2: implementation and beyond. Int $\mathrm{J}$ Ment Health Nurs2008; 17:65-72. [PubMed]

12. Janz NK, Champion VL, StrecherVJ:The health belief model. In: Glanz K, Rimer BK, Lewis FM, editors. Health behavior and health education: theory, research, and practice. San Francisco, CA: JosseyBass2002; pp. 45-66.

13. Turconi G, Celsa M, Rezzani C, Biino G, M A Sartirana M A and Roggi $\mathrm{C}$ :Reliability of a dietary questionnaire on food habits, eating behavior and nutritional knowledge of adolescents. Eur J Clin Nutr.2003 57, 753-763.

14. Gracey D, Stanley N, BurkeV, CortiB, Beilin L.J: Nutritional Knowledge, beliefs, behavior in teenage school students. Health Educ Res1996; 11(2):187-204.

15. Abdel-Hady D, El-Gilany A, andSarraf B: Dietary habits of adolescent students in Mansoura, Egypt. Int $\mathbf{J}$ Collab Res Intern Med Public Health 2014; 6 (6):123-144.

16. Heaney RP: Dairy and bone health. J. Am. Coll. Nutr. 2009; 28, 81S-90S.

17. World Health Organization :Diet, nutrition and the prevention of chronic diseases. World Health Organ Tech Rep Ser; 2003; 916(i-viii): 1-149.

18. Population Council: Survey of young people in Egypt. (SYPE). Final Report. Population Council. West Asia and North Africa Office; 2011. (Availableat:www.popcouncil.org/pdfs/2 010PGY_SYPE Final Report.pdf. Accessed April 7, 2013).

19. Fung T, andAnyan WR: Adolescence: life in the fast lane. In: Tamborlane WV, editor. The Yale guide to children's nutrition. New haven: Yale University Press 1997.

20. Stott-Miller M, Neuhouser M L, and Stanford J L: Consumption of deep-fried foods and risk of prostate cancer. The prostate 2013; 73 (9): 960-969, DOI: $10.1002 /$ pros. 22643.

21. LaKindJ, andNaiman D: Daily Intake of Bisphenol A and Potential Sources of Exposure: 2005-2006 National Health and Nutrition Examination Survey. J Expo Sci Environ Epidemiol.2011; 21: 272-279.

22. Hassan-Wassef H: Food habits of the Egyptian: newly emerging trends. East Mediterr Health J2004; 10(6):898-915.

23. Popkin BM, Armstrong LE, Bray GM, Caballero B, Frei B, Willett WC: A new proposed guidance system for beverage consumption in the United States. Am. J. Clin. Nutr. 2006; 83:529542.

24. Health Canada: Caffeine, it's Your Health.2010<http://www.hc-sc.gc.ca/hlvs/iyh-vsv/food-aliment/caffeineeng.php> (accessed 15.07.13).

25. Mullen M and Shield J E: Water: How Much Do Kids Need? Available at www.eat right. Academy of Nutrition and Dietetics Org 2015. (Access March 25, 2016).

26. Lock K, Pomerleau J, Causer L, Altmann DR, Mckee M: The global burden of disease attributable to low consumption of fruit and vegetables: implications for the global strategy on diet. Bull World Health Organ 2005; 83: 100-8.

27. Kaur T J, Kochar G K and Agarwal $\mathrm{T}$ : Impact of Nutrition Education on Nutrient Adequacy of Adolescent Girls. Stud. Home Comm. Sci. 2007; 1(1): 5155.

28. Ramic E, Kapidzic-Durakovic S, Karic E, Batic-Mujanoric O, Alibasic E, Zildzic M.: Influence of lifestyle on overweight and obesity in school-age children. Med Arh 2009; 63: 280-3.

29. Deheeger M, Rolland-Cachera MF, Fontvielle AM. Physical activity and body composition in 10 year old French children: linkages with nutritional intake? International $\mathrm{J}$ Obes Related Metab Disord 1997; 21: 372-9. 
30. Kim E J, Pai A J, Kang N, KimW $\mathrm{K}$, Kim Y S, Moon H, and $\mathrm{Ha} \mathrm{A} \mathrm{W}$ : The effects of food safety education on adolescents' hand hygiene behavior: an analysis of stages of change. Nutr Res Pract 2012; 6(2): 169174. doi: $10.4162 /$ nrp.2012.6.2.169.

31. Sharma S and Chawla P K: Impact of nutritional counseling on anthropometric and biochemical parameters of school girls (7-9 years). Anthropologist 2005; 7(2): 121-125.
32. Janz NK, Champion VL, StrecherVJ:The health belief model. In: Glanz K, Rimer BK, Lewis FM, editors. Health behavior and health education: theory, research, and practice. San Francisco, CA: Jossey-Bass 2002; 45-66.

33. Hazavehei SM, Taghdisi MH, Saidi M: Application of the Health Belief Model for osteoporosis prevention among middle school girl students, Garmsar, Iran. Educ Health (Abingdon) 2007; 20(23) [PubMed]. 